\title{
THE MODEL OF MARKETING COMMUNICATIONS EFFECTIVENESS: EMPIRICAL EVIDENCE FROM SLOVENIAN BUSINESS-TO-BUSINESS PRACTICE
}

\author{
Damjana Jerman ${ }^{1}$, Bruno Završnik ${ }^{2}$ \\ ${ }^{1}$ Faculty of Tourism Studies-Turistica, University of Primorska, \\ Obala 11a, 6320 Portorož, Slovenia \\ ${ }^{2}$ Faculty of Economics and Business, University of Maribor, \\ Razlagova 20, 2000 Maribor, Slovenia \\ E-mails: ${ }^{1}$ damjana.jerman@turistica.si (correspondingauthor); ${ }^{2}$ bruno.zavrsnik@uni-mb.si \\ Received 13 April 2011; accepted 30 August 2011
}

\begin{abstract}
The paper's purpose is to add to the body of knowledge on marketing communication effectiveness by developing and testing the model of marketing communication effectiveness in the business-to-business markets. Based on past research from the marketing communications and business-to-business marketing literature, the model is tested to examine the impact of antecedent variables on marketing communications effectiveness and organizational performance. Our analysis indicates that a central concept of marketing communication effectiveness is influenced by different variables. We also confirmed a positive impact of marketing communication effectiveness on organizational performance in case of Slovenian companies.
\end{abstract}

Keywords: marketing communication effectiveness, business-to-business markets, marketing communication objectives, communication channels, organizational performance, structural equation modelling.

Reference to this paper should be made as follows: Jerman, D.; Završnik, B. 2012. The model of marketing communications effectiveness: empirical evidence from Slovenian business-tobusiness practice, Journal of Business Economics and Management 13(4): 705-723.

JEL Classification: C83, M21, M30, M31, M37.

\section{Introduction}

This paper focuses on a new model for marketing communication effectiveness in the business-to-business context. Any company can develop a marketing communication program, regardless of budget or staff size. The key to implementing a successful program, however, is to incorporate measurement and analysis right from the beginning of marketing communication programme (Jerman 2007).

In recent years, the business-to-business marketing has experienced significant progress due to a number of theoretical and empirical findings published in the journals that examined the business-to-business market. A number of authors have written about the role and importance of marketing communications in the industrial markets (Smith et al. 
2004; Garber, Dotson 2002; Rinallo, Borghini 2003; Kitchen, Schultz 2003; Wickham, Hall 2006; Hall, Wickham 2008). However, marketing communication in the businessto-business markets offers further potentially valuable opportunities of research, especially empirical research.

With the increasing call for accountability of significant marketing communication spending, measuring the contribution of marketing communication effectiveness to firm performance is inevitable and valued (Kitchen, Schultz 2009; Ewing 2009; Rust et al. 2004). Many competitive organizations have implemented effective marketing communication in order to continually seeking better performance. There is an evidence to indicate that marketing communications effectiveness has a direct impact on organizational performance (Reid 2005; Pickton, Broderick 2001; De Pelsmacker et al. 2004). Luo and Donthu (2006), Duncan and Moriarty (1998) and Keller (2009) argued that marketing communications can contribute to brand equity as well as drive sales and profits and even affect shareholder value. Market performance as a type of organizational performance is typically related to market communication effectiveness expenditures for such variables as market share and sales. Also Rust et al. (2004) find that marketing communication effectiveness can influence a firm's market share and sales, thereby influencing its competitive market position. But the impact of marketing communications on organizational performance is not well documented yet because of a lack of valid measures of the marketing communication construct (Lee, Park 2007; Eagle, Kitchen 2000). Some responses to the intangible asset valuation problem of organizational performance have also been presented in the literature (Ratnatunga, Ewing 2005).

Some author argued that establishing right values and ethical standards build organizational performance (Potocan, Mulej 2007; Potocan et al. 2008; Saee 2005). However, measuring marketing communication impact on organizational performance has historically proven to be difficult, if not impossible. Benkahla (2006) argues that integrated marketing communications still has no standard form for testing its effectiveness. Reid, Luxton and Mavondo (2005) argue that the problem associated with such performance measure for marketing is the conceptualization of marketing inputs. Marketing communications results have historically been measured on a medium-by-medium basis: One measure for advertising, another for publicity, still another for sales promotion, and so on (Ewing 2009; Kim et al. 2004). These issues regarding the measurability of marketing communication programmes have also been a focus of discussion among academics and practitioners since the early stages of the development of the integrated marketing communications concept (Kliatchko 2009).

In recognizing this complexity, this paper attempts to explain the effect of different factors on marketing communication effectiveness and subsequently on organizational performance. We hypothesize that a company's marketing communications effectiveness generates favourable organizational performance in Slovenian companies. In this context, we explore marketing communications effectiveness and how this effectiveness can influence organizational performance of selected firms. A firm should have a business model that tracks how marketing communications effectiveness influences what its customers know, believe, and feel, and ultimately of course how they behave. 
Another contribution of this paper is that it tests the model of marketing communications effectiveness within a nomological net of antecedents and consequences. A unique contribution is an examination of the effect of marketing communication effectiveness on performance measure; we include such outcomes as market and financial performance when assessing the effect of marketing communication effectiveness on a firm. By adopting this approach, we offer a framework to other managers for how to enhance the effectiveness of their marketing communications. In terms of contributions, this model provides managers a priori basis for focusing their efforts on the antecedents of whole marketing communications effectiveness which produces a much higher effect on organizational performance.

\section{Literature review}

The literature offers limited empirical and theoretical insight into marketing communications effectiveness in business-to-business marketing. Specifically, there is little help for marketing communications managers when planning effective communications strategies and understanding their impact on organizational performance. We build on these gaps by exploring different factors that can impact marketing communications effectiveness, including the effects of these factors on actual market performance.

Business-to-business customers behave differently, are motivated by different criteria, and buy differently. The literature suggests that selling to business buyers is much different than selling to end consumers. The business customer is usually more knowledgeable and seeks more information, and the products and services offered to business customers are usually more complex. The differences between industrial or businessto-business marketing and consumer marketing are not in the concept, nor indeed in their value or relevance. Rather the differences are found in the techniques employed, the nature and complexity of purchasing decision-making, and the size of the budgets available for achieving these objectives. It has been posited that different instruments used in marketing communications' targeting business customers play more of an informational and supportive role than do those marketing communications that target final or end consumers (Grove et al. 2007).

The particularities of marketing communications in the business-to-business markets are evident, especially in the composition of a marketing communication mix, which will depend on various market factors. A relatively small number of participants and the complexity of purchasing decisions in business-to-business markets usually require more involvement and the least disturbed two-way exchange of information. In the case of complex technical products and services, where several persons are involved in the purchase and decision-making process, interpersonal communication is the best way to present such products or services and their properties.

Since there is two-way communication involved, the seller may hold the buyer's response to the perception of that product/marketing information; to adapt and keep this process eliminates any confusion or doubt. This process was adapted to the choice of ways to deliver marketing communication, among which is the domination of by direct personal contact. Throughout the marketing communication mix in the industrial 
market, the sales staff has the biggest influence on customer attitudes. The buyer in the business-to-business markets prefers communication tools that allow a direct and interactive exchange of information like direct mail, fairs, conferences, and visits of sales representatives (Rinallo, Borghini 2003). However, there exists limited literature that explores marketing communication in the business-to-business context (Low 2000; Garber, Dotson 2002; Kitchen, Schultz 2003; Hall, Wickham 2008; Grove et al. 2007).

The literature on marketing communications is broadly made up of a body of literature related to Integrated Marketing Communications (IMC), as firms have become interested in integrating their marketing communications for better results. IMC is one of the most debated topics in the current marketing communications literature. That literature contains a number of research studies that focus on a variety of issues. For example, Gould (1999) and Kitchen (1999) surveyed multinational advertising agencies on their use of integrated marketing communications for global customers. Low (2000) surveyed different types of organizations to determine which are most likely to employ an integrated marketing communications strategy. Reid et al. (2001) surveyed wineries to determine whether the brand associated with implementation differed for those firms that undertake an integrated marketing communications strategy. In summary, two points emerge from an examination of the existing research on integrated marketing communications. First, there is a lack of available research designed for testing integrated marketing communications in a business-to-business context. Second, there is a general agreement that much more research in this area is needed.

To the extent that marketing communication can be influenced by different factors through constructs, it is important for marketers to understand the collective contribution of those factors to the overall effectiveness of their marketing communications.

\section{Conceptualisation of marketing communication effectiveness and its related constructs}

Interactions that occur among marketing communications variables form an important aspect of our understanding of marketing communication effectiveness overall. The effectiveness of marketing communications has been examined by innumerable authors (Schultz, Patti 2009; Evans, Fill 2000; Rust et al. 2004; Smith et al. 2006). In order to develop further investigation in this research area, it is necessary to adopt first a perspective for defining actual marketing communication effectiveness and its associated concepts. Next, it is necessary to identify or, alternatively, develop a valid, reliable measurement scale to use to evaluate these proposed concepts.

In justifying and presenting our proposed model, the following five concepts were conceptualized for the purpose of Structural Equation Modelling (SEM) application in the context of marketing communications effectiveness in a business-to-business context: marketing communication objectives, bidirectional communication, communication channels, marketing communications effectiveness, and organizational performance. We also highlighted the various approaches to conceptualizing these concepts and identified the linkages between them. 


\subsection{Marketing communication objectives}

Properly configured objectives of marketing communications will have a positive impact on effectiveness. This presumption is clear from the objectives of the integrated approach, as developed by Fisher, Maltz, Jaworski (1997) and is based on the coordination behaviour of individuals and groups within an organization with a view toward achieving the identified objectives. The approach is also based on cooperation and interaction between the groups. Effective marketing communications is the result of coordinated operation between the functions of an organization and its chosen strategy of marketing communication resulting from both strategic goals and business strategy organization (Kliatchko 2009; Reid 2003). These correlations conclude that the development of marketing communication objectives and coordination with firm business strategy can lead to a consistent and workable strategy of marketing communication.

A strategy of marketing communication should be in line with the vision, strategy, and mission of the organization (Fill 1999) and in line with the chosen market strategy (Duncan, Moriarty 1998). Results of some studies demonstrate the positive impact of the mission of an organization on its financial performance.

For effective marketing communications, it is necessary that there be consistency among all communication messages, so that trust can be built and there can be coherence in target audience perceptions. The key to managing the point of perception is to deliver and receive messages on a platform of strategic consistency (Kitchen, Schultz 2003). In line with market orientation, the sharing of information across departments, the involvement of all departments in the preparation of business plans and strategies, the interactions of marketing personnel with other departments, are the needed prerequisites for best interfunctional coordination (Reid et al. 2005). Therefore, we hypothesize that:

H1: Marketing communication objectives positively associate with marketing communications effectiveness.

\subsection{Bidirectional communication}

Numerous studies have emphasized the role of high involvement in the communication message and its impact on changes in customer attitudes toward certain brands. The elaboration likelihood model for processing that information emphasizes the ability of communication to process and the motivation for processing the determined communication message. In order to initiate certain stimuli at the customer, the communication messages may differ both in content, which can has informative or emotional nature, and design and creative communication strategy (Brengman et al. 2001).

IMC has traditionally been identified as persuasion, but in marketing relationships, however, communication serves roles other than persuasion, such roles as informing, listening and answering, which require interaction and two-way communication forms (Finne, Grönroos 2009). The increasing importance of communication in today's marketplace is demonstrated by its ability to manage two-way communication.

An important part of any communication model is feedback, through which the receiver's response is made known to the sender (Duncan, Moriarty 1998). Marketing 
communications also need to provide clarity and fast, pertinent, timely information, so decisions can be made. Effective marketing communication occurs when the consumer can correctly interpret the initial message as it was meant to be sent. This bidirectional communication produces effective marketing communications. Bidirectional communication is thus hypothesized as being positively related to marketing communications effectiveness. Therefore, we hypothesize that:

H2: Bidirectional communication positively associates with marketing communication effectiveness.

\subsection{Communication channels}

The marketing communication channel, which views human communication as a transmission process during which a message travels across a channel from a sender to a receiver, is represented by the communication dimensions of frequency and mode of communication (Goebel et al. 2004). Communication frequency refers to the amount of communication that occurs between an organization and its public (Schultz, Patti 2009). Communication mode is defined as the channel, formal or informal, through which such information is transmitted to target groups (Maltz, Kohli 1996; Mohr, Sohi 1995). Previous research has found that information disseminated in a formal manner is seen as more credible (Mohr, Sohi 1995).

Marketing communication channels are hypothesized to be positively related to marketing communication effectiveness. Therefore, we hypothesize that:

H3: Marketing communication channels positively associate with marketing communication effectiveness.

\subsection{Marketing communication effectiveness}

A study conducted by Low (2000) showed that implementing IMC (Integrated Marketing Communication) may be strongly related to better marketing results in terms of sales, market share, and profits for an organisation. In seeking to understand the effectiveness of marketing communications, researchers have traditionally relied on measures of awareness, recall, and recognition (Beerli, Santana 1999). Many authors, in their theoretical and empirical contributions describe the impact of marketing communications on the organization's performance, particularly with a view to improving relations between the organization and its public. Explanation can be found in the marketing communication effectiveness, and its impact on the organizational performance (Young, Aitken 2007; Kitchen, Schultz 2009).

Reid (2005) in a research model displays a potential way of measuring and evaluating the implementation of IMC. The results of his research show a strong and significant positive impact of the performance of IMC on market performance. The relationship between the marketing communication and organizational performance is an important area of research, but only a few empirical studies have supported this link (Cornelissen, Lock 2000; Low 2000).

An organization that possesses marketing communication capabilities can create successful communication programs and ensure long-term market performance. There is a 
positive impact between possessing strong marketing communication capabilities and organizational performance (Ewing 2009).

The success of an organization can also result from the effectiveness of its marketing communication. In this area, many authors highlight the positive impact of marketing communications on organization performance (Ewing 2009; Schultz, Kitchen 1997; Low 2000; Pickton, Broderick 2001). So, we hypothesize that:

H4: Marketing communications effectiveness positively associate with organizational performance.

\subsection{Organizational performance}

Organizational performance can be measured by subjective and objective indicators. Subjective indicators are based on the subjective assessment of the company's performance in comparison with its competitors, with the planned results, in comparison with the previous period, etc. More frequently used subjective measures are return on investment, profits, and sales (Strandskov 2010; Moore, Fairhurst 2003; Le MeunierFitzHugh, Lane 2009). Objective performance indicators are based on official data from the financial statements of the company.

Market performance is typically related to market communication effectiveness expenditures for such variables as market share and sales. Marketing communication effectiveness can influence a firm's market share and sales, thereby influencing its competitive market position (Rust et al. 2004).

While achieving improved sales and market share is essential to any marketing communication effort, many firms consider financial impact the most crucial measure of success for any marketing communication activity. Financial benefits from marketing communication effectiveness can be evaluated in several ways. Return on investment (ROI) is a traditional approach to use to evaluate return relative to the expenditure required to obtain that return. Financial performance involves an increase in revenues (Rust et al. 2004).

\section{Research design}

\subsection{Sample and data collection procedures}

The main research instrument for empirical investigation in this study, e.g. a questionnaire, was developed on a derived theoretical basis. Cover letters with questionnaires were mailed to corporate directors, marketing directors or directors of 1000 Slovenian enterprises. We choose the convenience sample. The survey was conducted in 2009. We determined there were 59 nondeliverable and noncompliance questionnaires (e.g. incorrect address, respondents reported they wouldn't respond to surveys). A total of 269 (210 usable) returned questionnaires represented a of $22.3 \%$ response rate, which was quite satisfactory, given that average top management survey response rate in business-to-business markets is approximately 15\% (Wilkinson, Young 2002). The results presented in this paper relate to the final sample of 210 respondents. The collected empirical data were processed with LISREL and SPSS. 
The relevant data of the companies were provided mainly by marketing directors $(28.6 \%$ of cases), followed by company directors or presidents of the managing board with $28.1 \%$, members of top management $(19.0 \%)$, business consultants $(9.0 \%)$ and head executives $(5.7 \%)$. Heads of public relations offices or heads of marketing and public relations offices answered at $7.2 \%$ and counselling specialists answered at $2.4 \%$.

Company size was determined in terms of number of employees. The sample consisted of $45.2 \%$ small companies, $23.8 \%$ mid- sized companies and $31.0 \%$ large companies. The companies included in the sample were distributed according to industries as follows: $42.4 \%$ of respondents belonged to production- oriented companies; $30.4 \%$ of respondents belonged to service- oriented companies; and $24.3 \%$ were trade- oriented companies. The sample included of $2.4 \%$ institutions and $0.5 \%$ government organizations.

\subsection{Measures of the variables}

The scales utilized for this study are taken from the literature in marketing communications and a business performance context with some modifications where needed to fit the current study context. All the constructs, e.g. marketing communication objectives, bidirectional communication, communication channels, marketing communication effectiveness, and organizational performance, were measured on a Likert scale. The respondents had to indicate their agreement with the statements on a 7-point Likert (1 strongly disagree to 7 strongly agree) scale.

Below is a description and the operationalization of each measure.

Marketing communication objectives

The construct "marketing communication objectives" was operationalized as a reflective construct and measured with a 5-item scale, consisting of items drawn from Fill (1999) and Duncan and Moriarty (1998).

\section{Bidirectional communication}

The construct "bidirectional communication" was also operationalized as a reflective construct and measured with a 4-item scale, consisting of items drawn from Fill (1999) and Duncan and Moriarty (1998).

\section{Communication channels}

The construct "Communication channels" was operationalized as a reflective construct that assessed the frequency of contact over different modes of communication. It was measured with a 2-item scale (Goebel et al. 2004).

\section{Marketing communication effectiveness}

Marketing communication effectiveness was operationalized as a reflective construct and measured on a 3-item scale adapted from Low (2000), Young, Aitken (1999), and Duncan, Moriarty (1998).

\section{Organizational performance}

The construct "Organizational performance" can be operationalized in different ways. Objective performance indicators, which are based on official data from the financial statements of the companies, where not used in this research. Respondents subjectively rate various aspects of organizational performance. The construct "Organizational 
performance" was operationalized as a reflective construct and measured with a 3-item scale, consisting of items drawn from Zahay, Griffin (2004), Priyanto (2006) and Rust et al. (2004). Three sets of organizational performance variables were included: financial effectiveness (i.e. ROI, profit), market effectiveness (i.e. market share, sales) and other types of organizational effectiveness (i.e. customer satisfaction, employee loyalty). It was used item parceling (combining items into small groups of items within scales or subscales) because of the advantages which point out different authors (Bagozzi, Edwards 1998). Item parceling can reduce the dimensionality and number of parameters estimated, resulting in more stable parameter estimates and proper solutions of model fit. Also Nasser and Takahashi (2003) support the use of parcels rather than individual items because parceled solutions can be expected to provide better models of fit.

Reliability and validity issues were addressed using such methods as exploratory factor analysis, reliability analysis, and convergent validity. To test the internal consistency of the measurement scales, a reliability analysis was conducted for each distinct dimension. Except for the measurement scale for communication channels and bidirectional communication, the coefficient alphas (Cronbach 1951) exceeded the suggested 0.80 level mentioned in the literature. Therefore, the measurement scales for marketing communication effectiveness and organizational performance demonstrated a relatively high degree of reliability. Construct reliability (CR) measures were used to assess the reliabilities of constructs in the study. The reliability coefficients ranged from 0.68 to 0.89 (see Table 1).

Table 1. Reliability coefficients

\begin{tabular}{lccc}
\hline \multicolumn{1}{c}{ Construct } & Number of & Cronbach's \\
Items & $\begin{array}{c}\text { Construct } \\
\text { Reliability } \\
\Omega\end{array}$ \\
\hline Marketing communication objectives (CTK) & 5 & 0.8573 & 0.89 \\
\hline Bidirectional communication (DK) & 4 & 0.7793 & 0.82 \\
\hline Communication channels (KP) & 2 & 0.6673 & 0.68 \\
\hline Marketing communication effectiveness (UTK) & 3 & 0.8684 & 0.89 \\
\hline Organizational performance (UO) & 3 & 0.8137 & 0.84 \\
\hline
\end{tabular}

A confirmatory factor analysis indicated the convergent validity of the scales: All latent variables exhibited indices above the reference values of the composite reliability index $\left(\rho_{\mathrm{c}}\right)$ and the variance extracted $\left(\rho_{\mathrm{v}}\right)$ (see Table 2$)$. Composite reliability and variance extracted fell above the 0.7 and 0.5 thresholds, respectively, representing a high degree of shared representation of the indicators with the construct.

We also applied the statistical test ANOVA to compare the mean score of the two latent variables, marketing communication and organizational performance among the following independent groups: small companies, mid-sized, and large companies. When respondents were divided regardless of their size, a statistical difference was not observed in the marketing communication components and organizational performance components. So we concluded that the means of different groups regarding the size of the company are equal. 
Table 2. Composite reliability index $\left(\rho_{\mathrm{c}}\right)$ and variance extracted $\left(\rho_{\mathrm{v}}\right)$ for the measurement model for marketing communications

\begin{tabular}{l|c|c}
\hline \multicolumn{1}{c|}{ Construct } & $\begin{array}{c}\text { Composite Reliability } \\
\text { Index }\left(\rho_{\mathrm{c}}\right)\end{array}$ & $\begin{array}{c}\text { Variance Extracted } \\
\left(\rho_{\mathrm{v}}\right)\end{array}$ \\
\hline Marketing communication effectiveness (UTK) & 0.885 & 0.719 \\
\hline Organizational performance (UO) & 0.825 & 0.615 \\
\hline Marketing communication objectives (CTK) & 0.873 & 0.582 \\
\hline Bidirectional communication (DK) & 0.827 & 0.570 \\
\hline Communication channels (KP) & 0.676 & 0.514 \\
\hline
\end{tabular}

\subsection{The model}

Convergent validity was determined from the measurement model by examining whether each indicator's estimated loading on its posited underlying factor was large. Anderson and Gerbing (1988) suggest that parameter estimates should be high in value and t-values should be statistically significant. The measures in the resulting measurement model showed acceptable convergent validity, with each measure being significantly related to its underlying factor and t-values were statistically significant (see Table 3; Fig. 1).

The analysis was conducted using the LISREL program, which provides a simultaneous test of measurement models and structural model (Diamantopolous, Siguaw 2000). Discriminant validity was established by determining that the average variance extracted (AVE) from each latent variable's measure was larger than its shared variance with any other variable. The overall fit was acceptable. Analysis of the structural equation modelling showed that the model fit the data. Nevertheless, this model fit did not state that

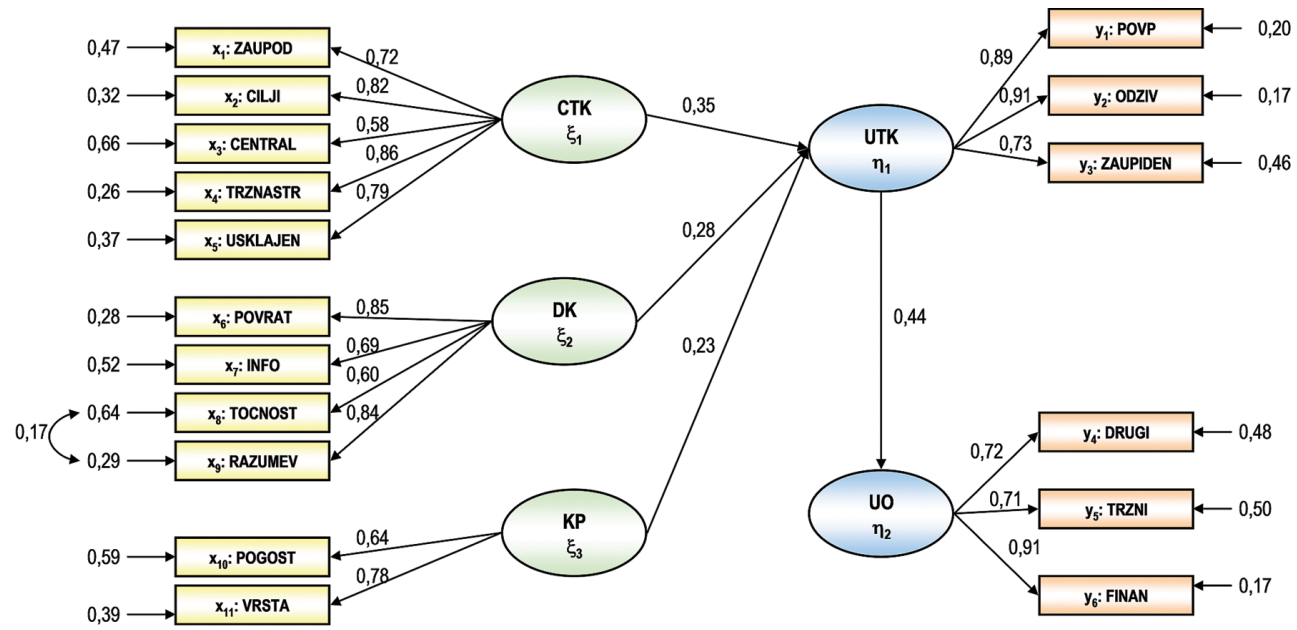

Model fit: $\chi^{2}=134.424 ; \mathrm{P}=0.065 ; \chi^{2} / \mathrm{df}=1.211 ; \mathrm{GFI}=0.930 ; \mathrm{NFI}=0.929 ; \mathrm{CFI}=0.986 ; \mathrm{RMSEA}=0.032$

Notes: CTK - Marketing communications objectives; UTK - Marketing communication effectiveness; DK - Bidirectional communication; UO - Organizational performance; $\mathrm{KP}$ - Communication channels

Fig. 1. Path diagram for the model of marketing communications effectiveness in the business-to-business markets 
Table 3. Standardized Solutions for the Measurement Model $(n=210)$

\begin{tabular}{l|c|c}
\hline \multicolumn{1}{c|}{ Construct and indicators } & $\begin{array}{c}\text { Completely } \\
\text { Standardized } \\
\text { Loading }\end{array}$ & $\begin{array}{c}\text { Variance } \\
\text { Extracted } \\
\mathrm{R}^{2}\end{array}$ \\
\hline$\xi_{1}:$ Marketing Communication Objectives (CTK) & & \\
\hline $\mathrm{X}_{1}:$ Trust and support of top management (ZAUPOD) & 0.724 & 0.524 \\
\hline $\mathrm{X}_{2}:$ Building on strategic objectives, vision and mission (CILJ) & 0.824 & 0.678 \\
\hline $\mathrm{X}_{3}:$ Centralization of implementation and control of marketing & 0.582 & 0.339 \\
\hline communication (CENTRAL) & 0.858 & 0.737 \\
\hline $\mathrm{X}_{4}:$ Consistency with marketing strategy (TRZNASTR) & 0.794 & 0.631 \\
\hline $\mathrm{X}_{5}:$ Consistency of communication messages (USKLAJEN) & & \\
\hline$\xi_{2}:$ Bidirectional communication (DK) & 0.845 & 0.714 \\
\hline $\mathrm{X}_{6}:$ Feedback (POVRAT) & 0.696 & 0.484 \\
\hline $\mathrm{X}_{7}:$ Communication messages contain enough information for a \\
purchase decision (INFO)
\end{tabular}

we could not find a more optimal structure model. Still, the overall fit was acceptable $\left(\chi^{2}=134.424 ; \mathrm{P}=0.065 ; \chi^{2} / \mathrm{df}=1.21 ; \mathrm{RMSEA}=0.032 ; \mathrm{GFI}=0.930 ; \mathrm{AGFI}=0.903\right.$; $\mathrm{NNFI}=0.983 ; \mathrm{CFI}=0.986 ; \mathrm{RMR}=0.048$ ). Thus, we can state that the model of marketing communication effectiveness for the business-to-business markets is appropriate.

Following the Anderson and Gerbing (1988) two-step approach for assessing the structural model, we estimated a series of nested models. We assessed whether any structural model would have acceptable goodness of fit. This was accomplished by a pseudo chisquare test: chi-square value for Ms (saturated structural model), in which all parameters relating constructs to one another are estimated) with degrees of freedom for $\mathrm{Mn}$ (largest for any structural model) was 365.1 (117 d.f.) (See Table 4 for the chi-square values for the models). 
Table 4. Nested models

\begin{tabular}{ccccc}
\hline Model & $\chi^{2}$ & $\mathrm{df}$ & $\mathrm{p}$ & CFI \\
\hline $\mathbf{M}_{\mathbf{s}}$ & 127,856 & 108 & 0.093 & 0.988 \\
\hline $\mathbf{M}_{\mathbf{u}}$ & 133,367 & 110 & 0.064 & 0.986 \\
\hline $\mathbf{M}_{\mathbf{t}}$ & 134,424 & 111 & 0.065 & 0.986 \\
\hline $\mathbf{M}_{\mathbf{c}}$ & 146,242 & 112 & 0.016 & 0.981 \\
\hline $\mathbf{M}_{\mathbf{n}}$ & 365,116 & 117 & 0.000 & 0.873 \\
\hline
\end{tabular}

Table 5. $\chi^{2}$ : Chi-square difference between models

\begin{tabular}{rccc}
\hline Models & $\Delta \chi^{2}$ & $\Delta$ df & $\mathrm{p}$ \\
\hline $\mathbf{M}_{\mathbf{t}}-\mathbf{M}_{\mathbf{s}}$ & $134.424-127.856=6.578$ & $112-108=4$ & $\begin{array}{c}\mathrm{p}>0.100 \\
\text { (not significant) }\end{array}$ \\
\hline $\mathbf{M}_{\mathbf{c}}-\mathbf{M}_{\mathbf{t}}$ & $146.242-134.424=11.818$ & $112-111=1$ & $\begin{array}{c}\mathrm{p}<0.001 \\
\text { (significant) }\end{array}$ \\
\hline $\mathbf{M}_{\mathbf{t}}-\mathbf{M}_{\mathbf{u}}$ & $134.424-133.367=1.057$ & $112-110=2$ & $\begin{array}{c}\mathrm{p}>0.900 \\
\text { (not significant) }\end{array}$ \\
\hline
\end{tabular}

We tested the chi-square difference between the proposed model and the saturated model: $\mathrm{Mt}-\mathrm{Ms}=6.58$ (4 d.f.). As the difference was not significant, the chi-square difference test was conducted between the constrained and proposed model: $\mathrm{Mc}-\mathrm{Mt}=$ 11.82 ( 1 d.f.). As it was significant, we finally tested the chi-square difference between the proposed and the unconstrained model: $\mathrm{Mt}-\mathrm{Mu}=1.06$ (2 d.f.) which was not significant (see Table 5). We would accept model Mt because it represents the most parsimonious structural model of the three hypothesized alternatives and because it provides adequate explanation of the estimated construct covariances. The fit of alternative more restricted model was significantly worse and the fit of alternative less restricted model was not significantly better. It was concluded that the theoretical model provided the better explanation.

\subsection{Results and discussion}

Several methodological issues with SEM application in the marketing communication effectiveness context were presented, including the Anderson and Gerbing (1988) two-step approach for assessing the structural model, operationalization of constructs, convergent and discriminant validity. SEM goodness-of-fit indices such as goodnessof-fit index (GFI), and comparative fit index (CFI) denoted that the hypothesized model had attained the requirement of a good and realistic model. SEM results indicated that marketing communication objective is the most crucial factor for improving marketing communications effectiveness.

The paper investigates the relationship between the effectiveness of marketing communications and organizational performance in the business-to-business markets in the case of Slovenia. The empirical research presented builds on the research model presented by many authors (Reid 2005; Low 2000; Ewing 2009; Schultz, Kitchen 1997; Pickton, Broderick 2001) that showed the relationship between the mentioned two key latent 
variables, marketing communications effectiveness and organizational performance. The research model presented in this paper evaluates the components of previous models and adapts them according to the contemporary body of knowledge from the field of marketing communications in the business-to-business markets. This study investigated only a portion of the factors that can affect marketing communication effectiveness in business-to-business markets. However, the tested model gave interesting results. To summarize, all the research hypotheses of the model, checked using the methodology for linear structural equations (SEM), were confirmed.

The analysis reveals that the domain factor that enhances marketing communication effectiveness in business-to-business markets is the achievement of marketing communication objectives. The results revealed that the construct "marketing communication objective" has a positive impact on marketing communication effectiveness (standardized coefficient $=0.35$ ) (see Fig. 1). This result supports Moorman and Miner (1998), Lynn et al. (2002) and Reid (2003), who stated that effective marketing communications is the result of the planned and coordinated operation between functions of the organization and strategy of marketing communication, which results from strategic goals and business strategy of the organization.

As Hypothesis 2 predicted, bidirectional communication has a positive impact on marketing communication effectiveness (standardized coefficient $=0.28$ ). Vakratsas and Ambler (1999) argued that marketing communication should focus more on the receivers and the meaning created by the receiver in the communication process. Duncan and Moriarty (1998) also confirmed that feedback is an important part of a communication model through which receiver response is made known to the sender. As a result, enhanced understanding of communication messages will generate effective marketing communication.

We also found a bit weaker - but still statistically significant - positive impact between the communication channel and marketing communication effectiveness (standardized coefficient $=0.23$ ). So, Hypothesis 3 was also supported. The confirmation of this relationship will create more interest for further research in this field. These results are in line with those of Dannaher and Rossiter (2011) who have explored the perceived relative effectiveness of communication channels in the business-to-business markets.

The latent variable "marketing communication effectiveness" also had a positive impact on the other endogenous variable of "organizational performance" (standardized coefficient $=0.44$ ). To summarize, Hypothesis 4 was confirmed. These results are in line with those of many other authors who have explored the impact of marketing communications on organizational performance (Kitchen, Schultz 2009; Young, Aitken 2007). Practitioners and academics put forward the notion that improvements in the management of marketing communications should lead to some level of superior organizational performance, in particular in the strength of brand relationships with customers and other stakeholders and the associated flow-ons from these relationships (McArthur, Griffin 1997; McGoon 1998; Pickton, Hartley 1998; Kitchen, Schultz 1999; Eagle, Kitchen 2000; Low 2000). 


\subsection{Directions of future research}

Surveys offer many opportunities for future research of organizations and how they achieve organizational performance through the effectiveness marketing communication. We tried to cover the factors that may affect the effectiveness of marketing communications, as well as empirically verify those consequences. However, there are still other opportunities to verify this conceptual model of marketing communications effectiveness. We highlighted certain factors that can impact the effectiveness of marketing communications, but at the same time we did not consider a number of external and internal factors of an organization that can affect such marketing communication. The most visible and profound opportunity for further research is focused on the link between marketing communication and other potential factors that may determine its effectiveness.

The interaction between individual instruments of the marketing mix (price, product, distribution, and marketing communications) and organizational performance is one of the most fundamental areas of marketing management. Decisions on marketing mix are the main components of a marketing strategy used to achieve the objectives of an organization, i.e., organizational performance. Economic science has taken a major step in studying the impact of other instruments on marketing mix, and that study can have an impact on the business performance. Yet little research has focused on the link between the precise constructs of marketing communication and organizational performance.

\section{Conclusion and implications}

The model of marketing communication for business-to-business markets represents a new perspective in marketing research. The central concept of the effectiveness of marketing communication assumes that there are variables that can have a positive influence on the effectiveness of marketing communication. In undertaking this study, we wanted to underline that the central area of this research is still not sufficiently studied, which forms the basis for new empirical research in this field.

However, when we talk about marketing communication to business-to-business markets, we concluded that the research area is theoretically, and in particular, also poorly studied in empirical terms (Wickham, Hall 2006; Garber, Dotson 2002). This is due to a lack of empirical evidence on the effectiveness of marketing communication on these business-to-business markets, that represent a conceptual model which still has not verified the significant contribution to the field that marketing communication on the business-to-business markets can make.

Further, another important theoretical contribution will be to study the area of effectiveness of marketing communication. In doing so, we came to the conclusion that marketing communication objectives do have a major impact on marketing communication effectiveness and best explain success. We also found we can explain the positive impact of bidirectional communication on the effectiveness of marketing communication. The proposed positive relationship between communication channels and marketing communication effectiveness was confirmed. 
A further contribution would be confirmation of the positive relationship between marketing communication effectiveness and organizational performance. Another important theoretical contribution to the field would be further study of the effectiveness of marketing communication model from a strategic point of view, namely, as a central concept of the antecedents and consequences in a model for marketing communication effectiveness on business-to-business markets.

This paper contributes to the literature by developing a structural equation model framework as a response to the call made by marketing communication researchers (Low 2000; Reid et al. 2001). This call suggested the use of more exploratory research to better operationalize both the concepts of marketing communication effectiveness and organizational performance and confirm that relationship.

An important contribution to management not only results in better performance of marketing communication, but the possibility that organizations can actually measure the effectiveness of marketing communication in terms of increased response to increased demand, sales and increased trust of target groups. It is a given that measuring instruments are the basis for achieving the effectiveness of marketing communication, and consequently achieving organizational performance. With the possibility of measuring the effectiveness of marketing communication are also opportunities for greater success of organizations' operating in business-to-business markets. This contribution is important because the literature is filled with calls for more empirical research into the field of marketing communication in business-to-business markets. Designing and testing the conceptual model offered here does represent a modest first step in that direction.

\section{References}

Anderson, J.; Gerbing, D. 1988. Structural equation modeling in practice: a review and recommended two - step approach, Psychological Bulletin 103: 411-423.

http://dx.doi.org/10.1037/0033-2909.103.3.411

Bagozzi, R. P.; Edwards, J. R. 1998. A general approach for representing constructs in organizational research, Organizational Research Methods 1: 45-87.

http://dx.doi.org/10.1177/109442819800100104

Beerli, A.; Santana, J. 1999. Design and validation of an instrument for measuring advertising effectiveness in the printed media, Journal of Current Issues and Research in Advertising 21(2): 11-30.

Benkahla, S. M. 2006. A study of the history and use of integrated marketing communications within publications form 1991-2005, Isaac Reed School of Journalism at West Virginia University. Available from Internet: http://wwwlib.umi.com/dissertations/preview_all/1436603

Brengman, M.; Geuens, M.; De Pelsmacker, P. 2001. The impact of consumer characteristics and campaign related factors on brand confusion in print advertising, Journal of Marketing Communications 7: 231-243. http://dx.doi.org/10.1080/13527260127415

Cornelissen, J.; Lock, A. 2000. Theoretical concept or management fashion? Examining the significance of IMC, Journal of Advertising Research 40(5): 7-15.

Cronbach, L. J. 1951. Coefficient alpha and internal structure of tests, Psychometrika 16: $297-$ 334. http://dx.doi.org/10.1007/BF02310555 
Danaher, P. J.; Rossiter, J. R. 2011. Comparing perceptions of marketing communication channels, European Journal of Marketing 45(1/2): 6-42. http://dx.doi.org/10.1108/03090561111095586

De Pelsmacker, P.; Geuens, M.; van den Bergh, J. 2004. Marketing Communications: European Perspective. Harlow: Financial Times, Prentice Hall.

Diamantopoulos, A.; Siguaw, J. 2000. Indroducing LISREL: A Guide for the Uninitiated. London: Sage Publications.

Duncan, T.; Moriarty, S. 1998. A communication - based marketing model for managing relationships, Journal of Marketing 62: 1-13. http://dx.doi.org/10.2307/1252157

Eagle, L.; Kitchen, P. J. 2000. Brand communications and corporate cultures, European Journal of Marketing 24(5/6): 667-686. http://dx.doi.org/10.1108/03090560010321983

Evans, M.; Fill, C. 2000. Extending the communication process: the significance of the personal influencers in UK motor markets, International Journal of Advertising 19(3): 377-396.

Ewing, M. 2009. Integrated marketing communications measurement and evaluation, Journal of Marketing Communications 15(2-3): 103-117. http://dx.doi.org/10.1080/13527260902757514

Fill, C. 1999. Marketing Communications: Contexts, Contents and Strategies. London: Prentice Hall Europe.

Finne, A.; Grönroos, C. 2009. Rethinking marketing communication: from integrated marketing communication to relationship communication, Journal of Marketing Communications 15(2-3): 179-195. http://dx.doi.org/10.1080/13527260902757654

Fisher, R.; Maltz, E.; Jaworski, B. 1997. Enhancing communication between marketing and engineering: the moderating role of relative functional identification, Journal of Marketing 61: 54-70. http://dx.doi.org/10.2307/1251789

Garber, L.; Dotson, M. 2002. A method for the selection of appropriate business-to-business integrated marketing communications mixes, Journal of Marketing Communications 8: 1-17. http://dx.doi.org/10.1080/13527260252848041

Goebel, D.; Marshall, G.; Locander, W. 2004. An organizational communication-based model of individual customer orientation of nonmarketing members of a firm, Journal of Strategic Marketing 12: 29-56. http://dx.doi.org/10.1080/0965254032000171609

Gould, S. 1999. Agency perceptions and practices on global IMC, Journal of Advertising Research 39(1): 7-20.

Grove, S.; Carlson, L.; Dorsch, M. 2007. Comparing the application of integrated marketing communiciation (IMC) in magazine ads across product type and time, Journal of Advertising 36(1): 37-54. http://dx.doi.org/10.2753/JOA0091-3367360103

Hall, L.; Wickham, M. 2008. Organising IMC roles and functions in the business-to-business network environment, Journal of Marketing Communications 14(3): 193-206.

http://dx.doi.org/10.1080/13527260701789775

Jerman, D. 2007. Can public relations affect company's effectiveness? Managing global transition: globalisation, localisation, regionalisation, in Proceedings in $8^{\text {th }}$ International Conference of the Faculty of Management Koper University of Primorska, November 20-24, 871-878.

Keller, K. L. 2009. Building strong brands in a modern marketing communications environment, Journal of Marketing Communications 15(2-3): 139-155.

http://dx.doi.org/10.1080/13527260902757530

Kim, I.; Han, D.; Schultz, D. E. 2004. Understanding the diffusion of integrated marketing communications, Journal of Advertising Research 44(1): 31-45.

http://dx.doi.org/10.1017/S0021849904040024

Kitchen, P. 1999. A multi-country comparison of the drive for IMC, Journal of Advertising Research 39(1): 21-38. 
Kitchen, P.; Schultz, D. 2003. Integrated corporate and product brand communication, Advances in Competitiveness Research 11(1): 66-86.

Kitchen, P.; Schultz, D. 2009. IMC: new horizon/false dawn for a marketplace in turmoil?, Journal of Marketing Communications 15(2-3): 197-204. http://dx.doi.org/10.1080/13527260903003793

Kitchen, P. J.; Schultz, D. E. 1999. A multi-country comparison of the drive for IMC, Journal of Advertising Research 39(1): 21-36.

Kliatchko, J. 2009. The primacy of the consumer in the IMC: espousing a personalist view and ethical implications, Journal of Marketing Communications 15(2-3): 157-177.

http://dx.doi.org/10.1080/13527260902757621

Le Meunier-FitzHugh, K.; Lane, N. 2009. Collaboration between sales and marketing, market orientation and business performance in business-to-business organisations, Journal of Strategic Marketing 17(3-4): 291-306. http://dx.doi.org/10.1080/09652540903064860

Lee, D. H.; Park, C. W. 2007. Conceptualization and measurement of multidimensionality of integrated marketing communications, Journal of Advertising Research (November): 223-236.

Low, G. 2000. Correlates of integrated marketing communications, Journal of Advertising Research 40: 27-39.

Luo, X.; Donthu, N. 2006. Marketing's credibility: a longitudinal study of marketing communication productivity (MCP) and shareholder value, Journal of Marketing 70(October): 70-91. http://dx.doi.org/10.1509/jmkg.70.4.70

Lynn, G. S.; Lipp, S.; Akgün, A. E.; Cortez, Jr. A. 2002. Factors impacting the adoption and effectiveness of the world wide web in marketing, Industrial Marketing Management 31: 35-49. http://dx.doi.org/10.1016/S0019-8501(00)00104-8

Maltz, E.; Kohli, A. 1996. Market intelligence across functional boundaries, Journal of Marketing Research 33: 47-61. http://dx.doi.org/10.2307/3152012

McArthur, D. N.; Griffin, T. 1997. A marketing management view of integrated marketing communications, Journal of Advertising Research 37(5): 19-26.

McGoon, C. 1998. Cutting-edge companies use integrated marketing communication, Communication World 16(1): 15-20.

Mohr, J.; Sohi, R. 1995. Communication flows in distribution channels: impact on assessment of communication quality and satisfaction, Journal of Retailing 71(4): 393-416.

http://dx.doi.org/10.1016/0022-4359(95)90020-9

Moore, M.; Fairhurst, A. 2003. Marketing capabilities and firm performance in fashion retailing, Journal of Fashion Marketing and Management 7(4): 386-397. http://dx.doi.org/10.1108/13612020310496976

Moorman, C.; Miner, A. S. 1998. The convergence of planning and execution: improvisation in new product development, Journal of Marketing 62(July): 1-20. http://dx.doi.org/10.2307/1251740

Nasser, F.; Takahashi, T. 2003. The effect of using item parcels on ad hoc goodness-of-fit indexes in confirmatory factor analysis: an example using Sarason's Reactions to Tests, Applied Measurement in Education 16: 75-97. http://dx.doi.org/10.1207/S15324818AME1601_4

Pickton, D.; Broderick, A. 2001. Integrated Marketing Communications. Harlow: Financial Times, Prentice Hall.

Pickton, D.; Hartley, B. 1998. Measuring integration: an assessment of the quality of integrated marketing communications, International Journal of Advertising 17(4): 447-465.

Potocan, V.; Mulej, M. 2007. Ethics of a sustainable enterprise - and the need for it, Systemic Practice and Action Research 20(2): 127-140. http://dx.doi.org/10.1007/s11213-006-9055-Z

Potocan, V.; Mulej, M.; Cancer, V. 2008. Influence of values, culture, ethics and norms on economic results: case of Slovenia, Social Research 17(3): 373-395.

Priyanto, S. 2006. A structural model of business performance: an empirical study on tobacco farmers, International Journal of Business 8(1): 103-134. 
Ratnatunga, J.; Ewing, M. T. 2005. The brand capability value of integrated marketing communication (IMC), Journal of Advertising 34(4): 25-40.

Reid, M. 2003. IMC - performance relationship: further insight and evidence from the Australian marketplace, International Journal of Advertising 22: 227-248.

Reid, M. 2005. Performance auditing of integrated marketing communication (IMC) actions and outcomes, Journal of Advertising 4: 41-54.

Reid, M.; Johnson, T.; Ratcliffe, M.; Skrip, K.; Wilson, J. 2001. Integrated marketing communications in the Australian and New Zealand wine industry, International Journal of Advertising 20: 239-262.

Reid, M.; Luxton, S.; Mavondo, F. 2005. The relationship between integrated marketing communication, market orientation, and brand orientation, Journal of Advertising 34(4): 1-23.

Rinallo, D.; Borghini, S. 2003. A fair(Y) tale: the semiotics of B2B communication, in The $19^{\text {th }}$ IMP Conference, Lugano. Available from Internet: http://www.impgroup.org/paper_view. php?viewPaper=4401

Rust, R. T.; Ambler, T.; Carpenter, G. C.; Kumar, V.; Srivastava, R. K. 2004. Measuring marketing productivity: current knowledge and future directions, Journal of Marketing 68: 76-89. http://dx.doi.org/10.1509/jmkg.68.4.76.42721

Saee, J. 2005. Societal ethics and legal system facing contemporary marketing strategies: an Australian insight, Journal of Business Economics and Management 6(4): 189-197.

Schultz, D.; Kitchen, P. 1997. Integrated marketing communications in US advertising agencies: an exploratory study, Journal of Advertising Research 37(5): 7-18.

Schultz, D.; Patti, C. 2009. The evolution of IMC: IMC in a customer-driven marketplace, Journal of Marketing Communications 15(2-3): 75-84. http://dx.doi.org/10.1080/13527260902757480

Smith, T.; Gopalakrishna, S.; Chatterjee, R. 2006. A three-stage model of integrated marketing communications at the marketing-sales interface, Journal of Marketing Research 43: 564-579.

Smith, T.; Gopalakrishna, S.; Smith, P. 2004. The complementary effect of trade shows on personal selling, International Journal of Research in Marketing 21: 61-76.

http://dx.doi.org/10.1016/j.ijresmar.2003.04.003

Strandskov, J. 2010. Sources of competitive advantages and business performance, Journal of Business Economics and Management 7(3): 119-129.

Vakratsas, D.; Ambler, T. 1999. How advertising works: what do we really know?, Journal of Marketing 63(January): 26-43. http://dx.doi.org/10.2307/1251999

Wickham, M.; Hall, L. 2006. An examination of integrated marketing communications in the business-to-business environment: the case of the Tasmanian light shipbuilding cluster, Journal of Marketing Communications 12(2): 95-108. http://dx.doi.org/10.1080/13527260600615600

Wilkinson, I.; Young, L. 2002. Marketing in the third millennium: looking backwards and forwards, Journal of Business Research 55(2): 81-85. http://dx.doi.org/10.1016/S0148-2963(00)00142-9

Young, A.; Aitken, L. 2007. Measuring marketing communications: concentrate on outcomes, not outputs, Market Leader, 51-55.

Zahay, D.; Griffin, A. 2004. Customer learning process, strategy selection, and performance in business-to-business service firms, Decision Sciences 35(2): 169-203.

http://dx.doi.org/10.1111/j.00117315.2004.02338.x 
Damjana JERMAN is an Assistant Professor of Marketing at the Faculty of Tourism Studies University of Primorska and at International Business School in Ljubljana. She received a Ph.D. in Marketing in 2008 from the Faculty of Economics at the University of Ljubljana. In addition to teaching and researching, she is primary responsible for public relations and managing marketing communications programs in the logistical company Intereuropa Ltd. Co. Koper. Her research interests include empirical and theoretical issues in business-to-business marketing communications, public relations, consumer behaviour, logistical services and marketing communication strategy and implementation. She has published articles in domestic and international journals.

Bruno ZAVRŠNIK is Professor of Marketing in the Faculty of Economics and Business, University of Maribor. He teaches a variety of courses at the undergraduate and graduate levels at Faculty of Economics and Business.

His research interests include empirical and theoretical issues in B2B marketing communications, purchasing and supply chain management, negotiations strategy and tactics, retailing strategy and implementation. He has published articles in domestic and international journals. 